\title{
2 Young Moroccan-Dutch women on hajj
}

\section{Claiming female space ${ }^{1}$}

\author{
Khadija Kadrouch-Outmany and \\ Marjo Buitelaar
}

\section{Introduction: the hajj and other desires and pursuits}

Mecca is crowded during the hajj season. Immensely crowded, in fact, both day and night. Since the 1970 s, the number of pilgrims traveling to Mecca from all over the world to fulfill their hajj obligation towards God has exploded; by 2019, the numbers had risen to 2.5 million. ${ }^{2}$ To accommodate the mass of pilgrims, the Kingdom of Saudi Arabia is currently expanding the accommodation and related services in Mecca at an unprecedented speed (McLoughlin 2013, 242). The number of regulations to control the flow of haji pilgrims also increases. Pilgrims have no choice but to entrust the Saudi Ministry of Hajj with the regulation of their movements during the pilgrimage. They are not allowed to wander around freely outside the perimeters of the area where the hajj rites take place; their visa only permits access to the so-called Haram or sacred area surrounding Mecca. To enforce this regulation, pilgrims have to hand in their passports to Saudi officials upon entering the Haram area, and get it back only on the bus back to the airport.

Female pilgrims face additional restrictions. To begin with, women under the age of 45 who travel to Saudi Arabia can only obtain a hajj visa if accompanied by a mahram or male guardian. ${ }^{3}$ For single women this can be quite a challenge, not in the least because of the financial burden and the lottery system that many countries have introduced in order to handle the Saudi quota system. ${ }^{4}$ Also, regardless of age or marital status, due to Saudi gender-segregation regulations all female pilgrims face restrictions in their freedom of movement once they enter Saudi Arabia.

This chapter follows the movements of a small group of Dutch female pilgrims, most of whom with Turkish and Moroccan backgrounds and aged between 25 and 40, as they navigate gender-segregated localities at the three most important hajj sites: Mecca, Mina and Medina. We include instances in which the women complied with Saudi regulations as well as instances in which they challenged them. Adopting an intersectionality approach, we analyze how the women's responses to and evaluations of gender-segregation at these sites relate to their everyday life-worlds, more specifically to their self-conceptions as women and as Muslims. 
This chapter is based on research within a larger project on modern articulations of pilgrimage to Mecca. The point of departure of the project, and hence for this chapter, is that pilgrims' self-conceptions are informed by various cultural discourses or 'grand schemes' that shape their habitus (Schielke and Debevec 2012, 5). Such discourses shape the 'sensibilities', that is, the moral and aesthetic dimensions of the experiences and emotional lives of individuals (Mahmood 2009, 836). Our aim here is to demonstrate how the multifaceted needs and desires that result from being informed by various cultural models and ideologies simultaneously feature in the young women's expectations and practices during the hajj and the meanings they attach to their experiences.

Hajj performance derives its emotional power not in the least by allowing pilgrims to 'step in the footsteps of the prophet Muhammad' and re-enact episodes from Islam's early historiography. Despite the appeal of the hajj as going back to the very beginning of Islam, on a more general level this chapter sheds light on how the practices and meanings that make up the hajj are not static but are actively appropriated by pilgrims. They experience and interpret the pilgrimage within the context of their own life-worlds and in some respects adapt it to these life-worlds. Sometimes this adaptation takes the form of explicit efforts to challenge the hegemonic order, at other times appropriation takes the form of tacit renegotiating and re-creating prescribed practices and meanings. Our focus is therefore on how the religious motivations of the women whom we follow in this chapter for claiming 'female space' in the places where the hajj rites are performed interconnect with other desires and pursuits in their daily lives.

The chapter is structured as follows. In the next section, we will give a methodological account on the production and analysis of the data presented in this chapter. After discussing the analytical framework in a subsequent section, we then zoom in on women's responses to specific practices of gender-segregation in the three locations that are central to the hajj rites: Mecca, Mina and Medina. We will demonstrate that in each of the hajj sites discussed, women's conceptions and concerns about the 'mundane' and the 'sacred' intertwine. In the concluding section, we will discuss our findings within the wider theoretical framework of women's agency in their appropriation of space.

\section{Methodology: a multiple-voiced conversation}

The authors of this chapter are co-researchers in a subproject on the practices and meanings of the pilgrimage to Mecca for Dutch Muslims of Turkish and Moroccan descent within the larger hajj research project mentioned above. ${ }^{5}$ At the time of writing this chapter, 40 pilgrims who grew up in the Netherlands had so far been interviewed on the meaning to them of the pilgrimage to Mecca, among whom 27 women in the age group we focus on here. The selection of specific locations to study women's responses to 
gender restrictions, as well as the analysis of the data and the argument in this chapter are based on the knowledge and insights developed in the wider research project of both authors and were jointly written.

Besides conducting eight of the interviews for our joint subproject, the first author Kadrouch-Outmany also joined a group of pilgrims from the Netherlands on the hajj of 2016. As research data on the hajj produced through participant observation in situ are rare, our primary focus in the chapter is on the ethnographic data she 'collected' during the hajj of 2016. To show how the data was produced in close conversation with the women whom Kadrouch-Outmany joined on their hajj journey, in the ethnographic vignettes depicting women's responses to Saudi regulations concerning gender-segregation in Mecca, Mina and Medina, the voice of KadrouchOutmany is present in the form of the I-narrator presenting her observations and own experiences in the text that is provided in box. The analytical and interpretive texts in the chapter represent the voices of both authors.

The group that Kadrouch-Outmany traveled with consisted of 220 pilgrims, $80 \%$ of whom were younger than 45 years old. ${ }^{6}$ The numbers of male and female pilgrims were more or less equal. There were many young couples in the group, quite a few of whom in the company of parents, inlaws and/or siblings. In this sense, as our interviews indicate is often the case for pilgrims from the Netherlands, the hajj was very much a 'family affair'. In this specific group, the large majority of pilgrims consisted of Moroccan-Dutch citizens. In addition, there were some Dutch converts and Dutch-speaking pilgrims with Surinamese, Pakistani, Palestinian, Iranian, Iraqi, Afghani, Turkish backgrounds. We zoom in here on the experiences of a small group of young female pilgrims who kept each other's company much of the time.

Like other female pilgrims younger than 45 years old, Kadrouch-Outmany needed a mahram or male companion to get a hajj visa. Fortunately, her husband agreed to join her on this field trip. Not wanting to be separated from their two-year-old son, the couple took him along as well. Furthermore, they decided to undertake the journey not for fieldwork purposes only but also to fulfill their own obligation as Muslims to perform the hajj. Therefore, they fully participated in all hajj rites. ${ }^{7}$

From the outset, Kadrouch-Outmany was open and transparent to the travel agent and her fellow travelers about her visit to Mecca as both pilgrim and researcher. Most people were appreciative of her research interests and some agreed to a follow-up interview after their return home in the Netherlands. It is likely that some pilgrims in the group did not appreciate being included in a research project and for that reason kept their distance, which was not hard to do in a group of 220 pilgrims. On the whole, however, rapport was quickly developed with a considerable number of fellow group members. Traveling with a toddler certainly contributed in that respect; most pilgrims were happy to engage with him. The researcher's closest relationships were with pilgrims of her own gender and age group, 
but it was also easy to engage in informal interviews and small talk with pilgrims of other generations, particularly with women.

\section{Female agency and the appropriation of space}

Although most scholars in the social sciences and humanities distinguish between 'space' and 'place', there is no general agreement on how these concepts are to be defined (cf. Massey 1994, 157). For the sake of our argument here, we follow Setha Low $(2017,11-33)$ who uses 'space' and 'place' predominantly to refer to different geographical scales. In Low's use of the terms, a place is a special kind of physical space that is used for particular purposes and attributed specific meanings. Such places should not be conceived of as bounded, fixed or homogeneous. Rather, as Massey $(1994,5)$ argues: 'If (...) the spatial is formed of social relations at all scales from the local to the global, then place is a particular articulation of these relations'. A place therefore extends beyond the interrelations of those present in a specific place to the world outside it. It is in this open sense that we conceive of the various sites where hajj rites are performed as places; while the pilgrims gather at each hajj site to perform specific ritual obligations, on the basis of their positions in various sets of social relations, different groups and individuals bring in their own conceptions of how these obligations are to be carried out and interpreted.

As we will see, in many instances, Saudi regulations concerning gendersegregation demand that men and women perform the rites in different spatial areas. Since any differential allocation of space inevitably affects the practices and views of those involved, in line with Low's understanding of place and space, strictly speaking one could argue that single-gender locations at a particular hajj site are specific male or female places. As we will demonstrate, however, rather than possible gendered specificities, it is the religious nature of the activities performed by female and male pilgrims alike that were the women's main concern at the various hajj sites. We therefore refer to areas that are allocated to female pilgrims at the various hajj sites as 'space for women' or, alternatively, 'female space'. We do so exactly because the young women whose experiences and views we discuss claim equal gender rights in the performance of religious obligations, including the right to make equal use of the various hajj sites as their male counterparts rather than being relegated to a different place.

As Jacqueline Brown $(2005,8)$ argues, 'place is an axis of power in its own right', meaning that the materiality of spatial locations cannot be separated from their social, political and symbolic dimensions. The objections raised by the young female pilgrims we study in this chapter concerning the unequal distribution of space at hajj sites illustrate that physical space is always simultaneously embodied and symbolic; people's conceptions and experiences of physical space and its boundaries are informed by and, in turn, inform their self-conceptions and wider life-worlds. Since the women 
whose movements we follow operate in various intersecting cultural contexts and corresponding webs of power relations, the import, for instance, of religious and secular discourses that shape their spatial desires in the situations we discuss are difficult to disentangle. As we will demonstrate, in some instances, women referred to the spirit of Islam to claim gender equality, while at other times, rather than gender equality, the negative consequences on their spirituality of hindrances to optimal performance of hajj rites were at the forefront of their objections.

To analyze how people move through space as they go through their daily routines, French philosopher Michel de Certeau (1984) distinguished between 'strategies' and 'tactics'. Strategies pertain to the actions of those who have powerful positions in the wider web of relations through which space is organized, while tactics concern the quick moves, manipulations and diversions of those who make use of places that are controlled or regulated by others (de Certeau 1984, 6). De Certeau's theorization of how people use space in the practice of everyday life is a particularly apt heuristic tool to study women's appropriation of space during the pilgrimage. Adopting the distinction between strategic and tactical use of space, however, one risks representing the women discussed here as passive respondents to dominant spatial structures rather than approaching them as actors whose practices are constitutive of the place where they operate. Also, conceiving of women's agency in terms of resistance to domination relates to a particularly modern Western conception of the autonomous subject. Different societal constellations, however, produce different kinds of desire for agency. As anthropologists like Mahmood (2005) and Frisk (2009) have demonstrated for female members of piety movements in Egypt and Malaysia, for instance, the agency of the women they studied was not so much based on a desire to liberate themselves from male-dominated gender relations, but rather on a desire of self-realization in terms of submitting to God. Having grown up in the Netherlands in Muslim families with migration backgrounds in nonEuropean countries, the habitus of the women we focus on here is shaped by various cultural discourses simultaneously. Taking agency to refer to an individual's situated capacity for action and interaction (cf. McNay 2005, 182), we therefore approach the agency of the women under study in terms of the multiple sensibilities and the intentional and reflexive pursuit of various desires that inform their hajj practices and experiences at the same time.

As is argued in the introduction to this volume, although hajj is situated in an extra-ordinary place far removed from where the women studied live, their everyday concerns, practices and views travel with them. The aim of this chapter is to gain insights in how the daily life-worlds of the women we follow inform their negotiations of Saudi regulations concerning gender-segregation and their active appropriation of space at the various hajj sites in the sense of re-forming and re-creating it. In the next section, we will therefore first ask how the expectations and motivations of the women are related to the various cultural discourses or 'grand schemes' 
that inform their life-worlds (cf. Schielke and Debevec 2012). In the sections that follow, we will zoom in on how what De Certeau $(1984,6)$ would call their 'ways of operating' must be understood against the background of these motivations and expectations. More specifically, we will analyze how, in evaluating and challenging the boundaries of the space assigned to them, the young female pilgrims combine what to them is the spirit of the hajj with the value of gender equality.

\section{The haji, marriage and gender equality}

A first indication of the ways that various desires combine in the women's hajj practices and experiences comes to the fore in their motivations to perform the pilgrimage. As mentioned above, there were many young couples in the group of pilgrims Kadrouch-Outmany accompanied. When sharing stories with each other about their decision to perform the hajj that year, the most recurrent reason mentioned by young female pilgrims with whom Kadrouch-Outmany performed the hajj was related to a wish to start early married life by performing the hajj together with their spouses. For example, one woman stated:

When we got married we immediately decided to spend as little money as possible on the wedding, but rather go on hajj the same year. I got married last May, and we immediately decided to perform the hajj the same year.

Another woman similarly explained that she and her husband had wanted to perform the hajj together soon after their wedding. Since she got pregnant very quickly, however, the couple chose to postpone the sacred journey a few years. When their son was old enough to leave him in the care of others, the couple decided to realize their plan to celebrate their marriage by going on hajj:

God gave me this wonderful husband and I wanted to share our obligation to perform hajj with him. So instead of asking money or gold as a dower, I asked for the hajj. I got pregnant very quickly after our marriage, so we waited for our son to get a bit older and decided to embark on hajj together.

As the opening sentence 'God gave me this wonderful husband' in this excerpt indicates, wishing to start one's marriage by making the journey to Mecca together can be motivated by several factors. First of all, both the informal conversations during Kadrouch-Outmany's fieldwork and the interviews we did with other pilgrims of the same age group suggest that the aim of bonding through joint hajj performance plays an important role. Although, or maybe exactly because, hajj performance is physically 
quite demanding, it can be a very rewarding experience in a spiritual and emotional sense. To go through this special experience together and support each other when things get tough can bring husband and wife closer together. Second, going on hajj as a kind of religious honeymoon is also related to showing one's gratitude to God for having brought the couple together. Wishing to get God's blessings for the marriage or making a vow that the life the couple starts will be dedicated to serving God are other factors that were often mentioned by the people we interviewed as feeding their desire to perform hajj as a honeymoon trip. Last but not least, many recently wed pilgrims, both male and female, mentioned that sharing the journey of a lifetime with their spouse was in line with their desire to be equal partners in the marriage. ${ }^{8}$ Some of the women whom KadrouchOutmany accompanied on their hajj journey had studied together with their spouses or had jobs which require them to work alongside other men, and many of them were engaged in the same social activities as their partners. In their views, the spirit of the hajj reinforces the relationship of equality between their spouses and themselves. As one woman put it: 'For Allah man and woman are equal in marriage. And for Allah all people are equal during hajj'.

Wishing to begin one's marriage well and on an equal footing by performing the hajj together significantly raised the expectations of many couples concerning the journey. However well informed many were, it soon transpired that the young couples had not always realized just how gender-segregated many of the activities during the hajj in fact are. In many instances, the ideal of going through all the hardships of the pilgrimage side by side with one's spouse proved to be difficult to put into practice. This obviously caused disappointments and tensions.

In what follows, we discuss women's responses to such instances of gender-segregation in three different locations: Mecca, Mina and Medina. For each of these three hajj sites, we concentrate on the interplay between specifically religious and other considerations, more particular on views about gender relations that come to the fore in women's responses to the division of space at gender-segregated hajj venues. The I-narrator in the ethnographic vignettes situated in Mecca, Mina and Medina refers to Kadrouch-Outmany.

\section{Mecca}

Having arrived late at night in Mecca, our group had a good night of sleep before going to the Grand Mosque to greet the Ka'ba, and to perform the welcoming tawa âf. Afterwards, I joined a company of several male and female fellow travelers to stroll through the streets of downtown Mecca for a first exploration of the city. My companions and I noted that many shops and restaurants had gender-segregated 
areas. This amused us as being something typically Saudi; a touch of local folklore that made us realize we were in a very different setting than home. We also saw separate queues for men and women in front of bakeries and juice bars, and, even more amusing considering their being Western-owned chains, gender-segregated counters at Starbucks and fast food restaurants like Domino's Pizza and Kentucky Fried Chicken. With hundreds of thousands pilgrims needing to eat, the queues in front of these counters were very long. Noting that the queues for women were much shorter than those for men, my companions soon learned to use the gender-segregation to their own benefit by having the women order food.

They were much less amused by the way Saudi hajj regulations aim at reducing the mixing of genders in the Grand Mosque to a minimum. Both male and female pilgrims like to gather in the front of the prayer area in the mosque courtyard for contemplation or prayer while enjoying the beautiful view of the Ka'ba. Whenever the call for prayer is heard, however, guards hasten to summon the women to the rear of the prayer area where they have no view whatsoever on the Ka'ba.

On one such an occasion, I accompanied a young couple from our group to the Grand Mosque to perform our prayers. We were quite early and sat down on the first floor where we had a magnificent view on the Ka'ba. We used the time before the prayers to take some selfies, make videos, and eventually to do what we had come early for: saying $d u^{\prime} \bar{a}$ s, supplication prayers. When the call for afternoon-prayer was heard, the guards quickly approached us to summon my female companion and myself towards the area in the back. My female companion tried to negotiate with the official: she explained that she had been looking forward very much to the spiritual reward of performing her prayers with a close view on the Ka'ba. She suggested that if she would sit next to her husband, I could sit between her and a pillar, thus precluding any man from sitting next to me. The guard did not even look at her while she was trying to reason with him but only reiterated his order she and I move. Although șabr or patience is one of the virtues that pilgrims are expected to demonstrate during the hajj, my female companion could not help venting her frustration once we had moved to the back:

Well, here we are again, behind those ugly roadblocks. I can't even see the Ka'ba anymore! They really know how to ruin the atmosphere.

The guards do not always succeed in keeping the mosque area gendersegregated. Contrary to most mosques both in Saudi Arabia and elsewhere in the world, The Grand Mosque of Mecca has no separate entrances for men and women. When pilgrims perform the tawäf, men and women therefore circle together and cannot avoid bumping into each other every now and then. 
Although only few of the women whom we interviewed for our research project volunteered information about it, female pilgrims are generally aware that not all surreptitious physical contact is innocent. Encouraged by the \#MeToo movement, in 2018 a Pakistani woman posted a message on Facebook to complain about being sexually assaulted whilst performing the tawa $\mathrm{a}$. Since then, many women have felt empowered to break a taboo on criticizing such despicable behaviour at Islam's holiest site and share their own experiences of sexual harassment during the hajj on Twitter using the hashtag \#MosqueMeToo. ${ }^{9}$ Besides the desire to share the spiritual reward of performing the rites with one's spouse, then, another good reason to perform the tawäf in the company of one's husband - or any other mahram, for that matter - is that he can cover you by walking behind you, as some women told us they asked their husbands to do. For similar reasons, if a group of pilgrims performs the tawa $\bar{f}$ together, tour leaders often ask male pilgrims to form a circle around the female pilgrims. Another precaution that some women take is to wear a protruding rucksack that prevents men from getting too close to them.

When the call from the minarets announces the next prayer time, those circling the Ka'ba hold still and perform their prayers on the spot. Men and women thus do their prayers side by side here, which is against the wishes of the guards, but much to the appreciation of many pilgrims who interpret gender mixing during the tawāf and prayers as a symbol of the value equality of men and women in Islam. In all other parts of the mosque, however, guards see to it that many pray in the front and women in the back.

In downtown Mecca and in the Grand Mosque, then, the first contours of a certain pattern of appreciation of the division of male and female space began to suggest itself among the women with whom Kadrouch-Outmany traveled. Gender-segregation in restaurants and at counters did not upset but rather amused them. We would argue that one reason why they did not object to this particular Saudi organization of male and female space was that it actually worked to the women's benefit as they were served more quickly than men. Another reason was that they viewed this gender-segregation as a kind of local folklore. Although inspired by an interpretation of the Islamic doctrine they do not share, it did not negatively affect the women's ritual practices. They were more reluctant to be relegated to the rear areas of the Grand Mosque to perform their prayers behind men. The female pilgrims who commented on this mainly considered it unfair to be withheld the spiritually rewarding experience of praying in full view of the Ka'ba. Some added that in their view, separating male and female pilgrims was against the spirit of equality of all Muslims that characterizes hajj. Nevertheless, since ultimately these Saudi regulations did not hamper their religious activities as such, they did not seriously challenge them. Their willingness to accommodate would diminish, however, once the group left Mecca to go to the tent camp in Mina for the next hajj rites. 


\section{Mina}

After having performed the rites in Mecca, for the next five days pilgrims stay in Mina from where they travel to other hajj sites. ${ }^{10}$ Mina is a huge tent camp located about five kilometers east of Mecca. The camp consists of 100,000 air-conditioned tents where pilgrims of different nationalities are accommodated in separate areas. Men and women are not allowed to sleep together in Mina, so that couples split up and sleep in single-gender tents. Sleeping shoulder to shoulder on worn and slim mattresses in a tent with up to 100 fellow pilgrims, one's patience is tested to the limit during the sojourn in Mina. Younger pilgrims try to communicate with their spouses through their mobile phones, but this does not always work. Being exhausted by the heat and the crowd, spouses may fall asleep, or batteries run low as others beat you in getting to one of the few rare sockets to charge their phones.

And so it could happen that walking down the aisles between the tents during our first day in Mina, I bumped into a young woman from our group who was obviously very distraught. Tears running down her face, she told me she had just had a rather upsetting encounter with a few women in the tent. Wanting to unburden her heart to her husband, he appeared nowhere to be found, which aggravated her frustration:

I can't find my husband! Where are they when you need them most?! I can't reach him, I can't go into his tent, nobody knows where he is and I need him to comfort me.

Eventually the husband was reached and came to meet his wife in the aisle, who was close to a breakdown by the time he arrived.

Interestingly, many older women did not seem to be bothered by the gender-segregation and were more orientated towards each other than towards their husband or alternative male guardian. While they enjoy performing the hajj in the company of family members, the older women we have interviewed never mentioned the significance of hajj as bonding with one's spouse. An obvious explanation for this is that most of them have been together with their husband for a much longer period of time and have settled in their relationship. Another explanation, more pertinent to the discussion of space in this chapter, is that most first-generation Moroccan and Turkish migrants to the Netherlands have transplanted to their daily life-worlds in the Netherlands, the strong gender-segregation that characterized the spatial division of space in Morocco and Turkey in the 1950s and 1960 s, particularly so in rural areas. Therefore, these older women 
are oriented towards and invest much time and energy in bonding with other women. In a similar vein, it struck Kadrouch-Outmany and many younger women whom we interviewed that older women did not seem to be bothered by the lack of personal space in the tent, but actually seemed to be quite comfortable. Comparing the Moroccan context in which women of her generation had grown up and the Dutch context that the younger women are used to, in the following excerpt, an older woman in the tent offered the first author a convincing explanation for intergenerational differences in the experience of the space in the tent in Mina that come to the fore both in Kadrouch-Outmany's observations and in many of our interviews. Talking about her distressed daughter-in-law, the woman stated:

These young people are used to having it all for themselves! You all are so spoiled. You are used to having your own clean and tidy room, your own bed, your own closet. Living in Morocco as a child, I slept on the floor together with my six siblings in the same room where my parents slept on a bed. We lived in a three-bedroom house with three families. We shared everything, from rooms to toilet, clothes and food. Young people are used to have everything of their own.

Indeed, it is especially the young women who appear to be keen on hygiene and privacy and who avowed to feel extremely uncomfortable in the crowded tent camp. Elderly women would agree that the provisions in the tent were basic, but they did not seem much bothered by this. For many younger women accustomed to having personal space and time and a certain standard of hygiene, to the contrary, the lack thereof in the tent camp came as a 'culture shock'. As Kadrouch-Outmany noted, fellow pilgrims of her own generation complained a lot about the conditions in the tent and wondered how to devote themselves to spirituality in these circumstances. In the interviews that we did in the Netherlands, we noted that besides complaining about bad management and pilgrims being cheated by their travel companies, in hindsight quite a few of our interlocutors who commented on the situation in the Mina tents had reformulated the experience in terms of an important spiritual lesson: being thrown back on yourself one learns to be humble and reflect on what really matters in life.

For the specific group of women whom Kadrouch-Outmany accompanied on hajj, the lack of space inside the tent was not their biggest concern. ${ }^{11}$

By the end of their first day in Mina, all that the women around me seemed to be talking about were the toilets. Washing and toilet facilities are located outside the tents. For every $500-$ to 700 people in the tent area where the pilgrims from the Netherlands were staying, there 
were only 30 toilets/showers to share. Of these 30 toilets, 20 were to the men, and only 10 to the women. The queues at the women's toilets were at least 20 women deep, and waiting for one's turn could easily reach up to an hour and a half. Many women in the queues were screaming shouting and pulling, testing to the limit those who were trying to respect the ideals of the hajj and their state of ihräm by remaining patient and considerate. One young woman decided to check out the section with men's toilets. She reported on what she had found there with a mixture of amazement and anger:

Guess what: they don't have just 10 toilets like we do, they have 20 ! While they can do their ablutions in the washing area outside the toilets! Some toilets had one or two men waiting their turn, but there were no real queues! I told my husband to take it up with our organization, but they responded that the allocation of toilets is a Saudi thing so they can't interfere. Can you believe that? Saudis telling me where to pee!?

Many young women burst into laughter in response, bringing out in the open their shared indignation about the discriminatory sanitary arrangements. Why would men have more toilets and showers? Is it not exactly equality between all Muslims that, amongst others, the hajj symbolizes, some women argued?

This time, Saudi regulations of gendered space was no longer considered amusing. Instead, it infuriated the women. What made the situation particularly difficult to accept was that it hampered what they had come to do; queuing up for the toilet for an hour and a half meant that this waiting time could not be used to perform whatever spiritual activities they wished to engage in. Some women complained about having missed out on their fajr or early morning prayers because they had to wait too long to perform the ablution.

Determined to get access to more toilets, some young women worked out a plan; they suggested to forming a group and going up to the men's section to appropriate at least three toilets there. As they did so, the other women formed a queue. Some men did not react, but others got angry, screaming shouting things like,: 'The women's section is on the other side!' 'This is for men only!' 'Don't mix with the men!'. Some women clearly felt intimidated, but as agreed beforehand, most ignored the men. Coming out of the confiscated toilets, their faces expressed: 'Victory!'. The women's joint response to the shortage of toilets was highly effective: in the days that followed, the women had 13 toilets at their disposal. The time lost in line was reduced significantly, allowing more time for the women to engage in religious activities. 
Reflecting on this calculated action of repairing the unequal distribution of space, one can see the implication of the tactics the women employed. Mina, as well as the various other hajj sites they moved in, are controlled by the Saudi regime. The young women succeeded in actually changing the allocation of toilets as regulated by the officials in a peaceful, tranquil and confident way. Contrary to the areas where the actual rites are performed and that are associated directly with Islam's sacred history, Saudi surveillance at the toilet blocks was more or less absent. The women's 'tactical' maneuvers were not without effect; they successfully operated in a different mode than intended by the officials who control the tent camp. In this instance, it was difficult, if not impossible, to disentangle the various desires that motivated the women's action: they objected to the unequal distribution of space both because it symbolized men's privileged position and because waiting in line hampered their religious obligations, thus affecting their spirituality. On a more practical level, we surmise that their irritation was also fed by the fact that in their daily lives, they are accustomed to more comfort and higher hygienic standards than what they were confronted with in the toilet and shower arrangements in Mina. In this sense, multiple modern sensibilities interwove in how the young women experienced the restrictions on female space.

\section{Medina}

After completing the hajj and recovering from the days in the Mina tent camp in a luxurious hotel in Mecca, a bus drove Khadija-Outmany's group to the city of Medina, 450 kilometers north of Mecca, to visit the grave of the prophet Muhammad in the mosque called al-Masjid al-Nabawī. Families and spouses can sit together in the enormous mosque courtyard of the al-Masjid al-Nabawi between prayer times, but the mosque itself is completely gender-segregated. Guards see to it that men and women enter the building through separate entrances that give access to separate male and female sections. The Prophet is believed to have said that the mosque area between what used to be his house and the mosque pulpit is one of the gardens of Paradise. To perform a prayer in this so-called rawda equals the reward of 1,000 prayers. Pilgrims are very keen on visiting the rawda both for its religious merits and because of the physical proximity to the Prophet.

The rawda is located in the men's section of the mosque. Men are free to visit it at any time between the dawn prayer and the last evening prayer. Also, men visiting the rawda can actually see the structure that hosts the grave of the Prophet. Women, however, are confronted with several restrictions. First of all, the visiting hours for women are much shorter: during the hajj season in 2016, the rawda was open to women during the few hours between the last prayer in the evening and the first at dawn. Second, women cannot enter the whole rawda. The area accessible for them is shielded off with big screens, even though men do not visit the rawda 
simultaneously. The women's area covers only a fourth or less of the entire rawda. Most importantly, women are barred from seeing the grave of the prophet Muhammad.

On the second night of our stay in Medina, at ten o'clock I went down to the hotel lobby to join a group of young women to go to the rawda. A woman who had already been there the previous evening informed us what to do once we would get there:

Make sure to hold on to each other very tight when the guards announce that you may enter the rawda. Make pairs of two or three, and once you're inside make a circle and then let everyone of you do her prayers inside that circle. Otherwise women will just push you aside or even worse, step on you. It's very crowded and women push and pull and that's very scary when you're in sujūd [prostration]!

On our way to the mosque we felt excited and well prepared. When we found the entrance to the rawda and passed all the security checks, we entered a part of the mosque that looked like a waiting room. The rawda was some twenty 20 meters away from where we were seated and shielded behind white screens. One guard came to chat to our group and pointed out objects behind the screen:

'That is the top of the pulpit of the Prophet, and that is the top of the prayer niche of the Companions, and in the back there is the grave of the Prophet.'

Eagerly following the direction her finger pointed, all we could see of these objects were the very top parts that stuck out above the screens. To our left I saw something that looked like the top sill of a door. Noting what drew my attention, the helpful guard explained:

Ah yes! What you see there is the women's entrance to the mosque that the Prophet had provided for so that there would be no barrier for women, and so they would know they are free to enter the mosque to perform prayers.

This explanation struck me as ironic: the contrast between the situation described and the one we found ourselves in could not have been larger. After having waited for about an hour, the guards made an opening in the screens and summoned us to get up. All women rushed to the rawda simultaneously, many of them pushing or elbowing others aside to be among the first to enter. As we had been advised, the women with whom I had come made a circle to allow each of us enough space to take turns in performing a short prayer. We had barely finished when after half an hour the guards yelled that our time was up and started pushing us towards the exit. 
We left gravely disappointed. As soon as we got to the mosque courtyard one of my companions shared her indignation and disappointment and stated:

I never thought it would be like this. I can't imagine wanting to come here again, and having to push and pull myself in. That was really hard for me, I'm sure I hurt someone when we entered the rawda. I had imagined it to be different. My husband made it all look so relaxed and easy. We've only been in Medina for a day now but he has already visited the rawda several times, making plenty of pictures and selfies inside. Whereas I hardly saw anything, being with so many and all over each other in such a small space.

Another woman added:

This was absolutely nothing like I had imagined. I didn't feel close to the Prophet at all, and I didn't get a chance to do or say any of the things I had planned. I couldn't even reach my notebook with $d u^{\prime} \bar{a}$ s. I was more worried about keeping the circle intact, and when praying I was worried about my safety. I didn't really feel present. I'll come back better prepared tomorrow.

This young woman felt disillusioned and deprived of what should have been one of the spiritual highlights of her journey. She was determined to visit the rawda again the next day and suggested we join her. By then, we were mentally better prepared for the visual and physical limitations of the rawda. This time my companion was determined to do what she had not managed to do the night before; she first took out her notebook to say all the supplications she wanted, and then prayed in our protecting circle, and upon finishing her prayers she even managed to take a group selfie. Although it still hurt her that she was prevented from having visual or physical access to the grave of the Prophet, her disappointment had somewhat abated and having adjusted her expectations, she was pleased that at least she had managed to accomplish her most important religious goal of praying in the rawda.

To be sure, not all women who shared their stories about the rawda with us blamed the Saudi regime for the restrictions that female pilgrims face there. Pointing to the highly emotional response of many women who actually fought their way into the rawda to illustrate their point, some of our interlocutors stated that women tend to be more emotional than men. It is for this reason, they argued, that both female pilgrims themselves and the Prophet's grave need to be protected lest wailing women wreak havoc. ${ }^{12}$ 
Since men and women earn equal amounts of ajr or religious merit for praying in the rawda, according to the same women ultimately it does not matter that women's access is restricted. Thus, these women prioritized gender equity in the eyes of God over gender equality. Some other women, on the contrary, referred to this argument to criticize it as internalized sexist views from former times. Indeed, the indignation about Saudi regulations concerning gender-segregation at the rawda was shared by most of our younger female interlocutors. Some stated that because of their objections to the subordination of women in the ways the Saudi organized the hajj sites, they were relieved that since they now had fulfilled their religious obligation to perform the hajj, they would never have to visit Mecca again. Resonating with the findings of Nadia Caidi (2019) concerning the relationship between hajj expectations and experience, on the one hand, and the amount and nature of knowledge that prospective pilgrims have at their disposal, on the other hand, others reasoned that, being sadder but wiser, they might lower their expectations and give Mecca and themselves another chance.

\section{Conclusion}

What comes to the fore in the stories shared by the young female pilgrims we observed and talked with about gender-segregation during the hajj is that their negative experiences in the rawda was the most difficult for them to come to terms with. While some also criticized the rude behavior of fellow female pilgrims who shamelessly fought others off to obtain the best place to perform their prayers, the discriminatory nature of Saudi regulations concerning male and female access to what is considered to be 'one of the gardens of Paradise' was criticized most. What makes the situation in Medina different from instances of gender-segregation in Mecca and Mina is that in the rawda women are prevented from seeing or touching highly valued objects referring to the prophet Muhammad, while men do have access to them. Being deprived access to these objects for many amounts to actually being denied equal access to sacred space in comparison to men. The situation thus had a direct impact on the spiritual reward the women had hoped to experience during their hajj journey.

Intertwined with disappointment about the spiritual reward was indignation about the Saudi control of sacred space as being against the conception of Islam as a religion that stands for gender equality. As mentioned before, besides wanting to fulfill their religious obligation and a desire for spirituality, for many young women in the group that Kadrouch-Outmany followed as well as for a considerable number of the women whom we interviewed, performing hajj together with their husbands was also motivated by the wish to reinforce their mutual relationship as equal partners in their marriage. Although it had not been easy to spend time with their husbands in the tent camp, both in Mina and in Mecca the couples had been able to 
carry out hajj rites in each other's company to an extent that was impossible in the al-Masjid al-Nabawi. ${ }^{13}$

In terms of de Certeau, we can discern a pattern both in the strategic control over the hajj sites by the Saudi regime and in the tactical responses of the young women as they appropriated the space at these sites. The strongest surveillance was in places that are central to the hajj rites and therefore considered the most sacred. One obvious reason for this is that the flocking together of millions of pilgrims must be controlled to avoid accidents. Another reason is that presenting itself as the legitimate custodian of the Holy places is an important source of symbolic power for the Saudi regime (cf. Bianchi 2004, 45).

As came to the fore most strongly in the women's response to women's limited access to the rawda, gender-segregation at the most sacred places where spiritual reward is thought to be the highest is what upset the young women in particular. Separate sections for men and women at shops and restaurants did not bother them much; this practice could be subsumed under the rubric of local folklore and was turned into the women's advantage. More importantly, it was inconsequential for their devotional practices and the spiritual rewards of hajj performance. Things were different in the Grand Mosque in Mecca. There the women could be seen to make the quick moves, manipulations and diversions that de Certeau describes as characteristic of those who make use of a space that is 'owned' by others. Sometimes the women managed to circumvent the gaze of guards and stay together with their husbands in the mosque courtyard. But when they were ushered to the rear area, complaints and compliance went hand in hand. Although the women objected to the exclusive privilege of men to have a full view of the Ka'ba when performing one's prayers, it did not hamper their religious performance to pray further in the back.

De Certeau's argument concentrates on circumstances where people can exert only limited influence, thus subverting situations without deliberately challenging them. In Mina, however, by taking possession of three of the men's toilets the women openly resisted the gendered organization of space. That they succeeded in doing so is probably related to the fact that the toilet area is considered not just a mundane but a lowly valued space where control is lax. The women's motivation to appropriate more space for women in the toilet area illustrates that the use of tactical religion by 'ordinary' people has no clear-cut boundaries but can permeate different domains of life. Besides disapproving in principle of the unequal treatment of men and women, the women also objected to the sanitary arrangements because the long queues seriously hampered engaging in devotional practices.

In keeping with Schielke (2010), the fact that it were younger women who challenged the unequal distribution of space by the Saudi authorities, while older women seemed to comply willingly with the rules demonstrates that pilgrims' expectations and experiences of the hajj depend on the various cultural discourses that inform their life-worlds. For older women, gratitude about being 'called' by God to perform the religious 
obligation of hajj performance dominates, and they tend to humbly accept everything that comes with it, finding it inappropriate if not blasphemous to criticize anything related to the holiness of Mecca. This is in line with how they have been brought up: most of them were born in rural Morocco or Turkey, where, besides being accustomed to harsh conditions, most of them had learned to accommodate the notion that women come second after men.

The life-world of the younger women differs considerably. In the most practical sense, having grown up in the Netherlands, their embodied experience of gendered space is informed by their being accustomed to privacy in the sense of space and time to themselves as individuals as well as to high standards of comfort and hygiene. In terms of religiosity, the meaning of hajj seems to have shifted from a focus on fulfilling a religious obligation and act of penitence that characterized the expectations and motivations of older generations, to enjoying the pilgrimage for its spiritual reward and a means of spiritual self-enhancement (Buitelaar 2020; 2018). Also, having been educated in Dutch schools and generally having (or looking for) jobs themselves rather than depending on the income of husbands, the young women have internalized discourses about gender equality. Maybe most importantly, they have learned to speak up for themselves. These intergenerational differences inform the religious styles of the women. For older women, hajj is mostly about paying one's debt to God and asking for forgiveness. While younger women acknowledge these meanings of the pilgrimage, for them the desire to experience the sacred atmosphere as an aid to spiritual self-formation is of at least equal concern. ${ }^{14}$

For the younger women whom Kadrouch-Outmany accompanied on their hajj journey, finding a solution for such a seemingly mundane matter as sanitary arrangements thus came to stand for much larger issue of gender equality in Islam, demonstrating that the desires and sensibilities of these women are not only informed by principles that they derive from Islamic sources, but also include liberal political concepts such as rights and equality. ${ }^{15}$

\section{Notes}

1 We would like to thank the Netherlands Organization for Scientific Research (NWO) for their generous grant (360-25-150) for the research project 'Modern Articulations of Pilgrimage to Mecca' on which this chapter is based.

2 https://www.arabnews.com/node/1538466/saudi-arabia

3 For an historical overview of how scholars within the various Islamic Law Schools have debated regulations for female pilgrims, see Sayeed 2016. For present-day implications of the current Saudi mahram regulations for women and for stories about the different ways in which female pilgrims deal with them, also see the contributions of Al-Ajarma, Buitelaar and Thimm in this volume.

4 cf. see the contribution by Al-Ajarma in this volume.

5 Two other contributors to this volume, Richard van Leeuwen and Kholoud Al-Ajarma, also participate in the larger research project. 
6 The composition of hajj groups can vary considerably depending on the travel agency that the pilgrims travel with: some travel agencies work predominantly through mosques who book package tours for members from their own congregation who are guided by their own imam. Older generations of Muslims in the Netherlands tend to prefer these tours in which one travels in the company of people one knows. Other travel agencies are very active in marketing 'premium' package tours that appeal mostly to more affluent and also more demanding younger Muslims. Some target clients of specific ethnic backgrounds, others advertise an inclusive approach (personal communication Said El-Amraoui of Hadjinfo).

7 Kadrouch-Outmany has reflected on participating in the hajj as an insider's outsider in Kadrouch-Outmany 2018a.

8 To be sure, our interviewees mentioned other, more pragmatic reasons as well; it is easier to perform hajj before getting children for whom caretakers would have to be found. Also, since one should not have any debts when undertaking the hajj, it is convenient to perform it before getting a mortgage for a house.

9 Note that a few years earlier, Eltahawy $(2015,48-52)$ already reported about being sexually assaulted during the hajj. At that time, however, her testimony was not picked up.

10 The most important rituals of hajj start in Mina. First is the standing at the mount Arafat to contemplate one's life and ask God for forgiveness, followed by spending the night in the open in Muzdalifa to collect pebbles, which on three subsequent days are used for the rite of throwing seven pebbles at the jamarāt, pillars that represent the Devil.

11 Due to limited space in this article, we only focus on one specific mundane struggle in this section. Obviously there were many more ranging from getting food and medical help to charging mobile phones.

12 The view that women should be forbidden to attend funerals because of their perceived emotional nature is more commonly found among Muslims of different cultural backgrounds, cf. for example Kadrouch-Outmany 2018b.

13 The strict Saudi control over access to the grave of the prophet Muhammad is not only related to Wahhabi views on gender relations, but also to the view that veneration of the dead, including the Prophet, is forbidden. This contravenes the religious views of the majority of Muslims from other religious denominations.

14 cf. Haq and Jackson (2009), who observed similar intergenerational differences between Pakistani-Australian Muslims.

15 cf. Hafez (2011), who builds a similar argument for Egyptian women active in revivalist movements.

\section{References}

Bianchi, Robert, 2004. Guests of God. Pilgrimage and Politics in the Islamic World. Oxford: Oxford University Press.

Brown, Jacqueline Nassy. 2005. Dropping Anchor, Setting Sail: Geographies of Race in Black Liverpool. Princeton, NJ/Oxford: Princeton University Press.

Buitelaar, Marjo. 2020. 'Rearticulating the Conventions of Hajj Storytelling. Moroccan-Dutch Female Pilgrims's Multi-voiced Narratives about the Pilgrimage to Mecca.' Religions 11 https://doi.org/10.3390/rel11070373

. 2018. 'Moved by Mecca. The Meanings of the Hajj for Present-day Dutch Muslims.' In Muslim Pilgrimage in Europe, edited by Ingvild Flaskerud and Richard Natvig, 29-42. London/New York: Routledge. 
Caidi, Nadia. 2019. 'Pilgrimage to Hajj: An Information Journey.' The International Journal of Information, Diversity \& Inclusion 3 (1): 44-76.

de Certeau, Michael. 1984. The Practice of Everyday Life. Translated by Steven Rendall. Berkeley: University of California Press.

Eltahawy, Mona. 2015. Headscarves and Hymens. Why the Middle East Needs a Sexual Revolution. New York: Farrar, Strauss and Giroux.

Frisk, Sylva. 2009. Submitting to God. Women and Islam in Urban Malaysia. Copenhagen: NIAS Press.

Hafez, Sherine. 2011. An Islam of Her Own. Reconsidering Religion and Secularism in Women's Islamic Movements. New York/London: New York University Press.

Haq, Farooq and John Jackson. 2009. 'Spiritual Journey to Hajj: Australian and Pakistani Experience and Expectations.' Journal of Management, Spirituality and Religion 6 (2): 141-156.

Kadrouch-Outmany, Khadija, 2018a. 'Antropoloog in Mekka. Onderzoek Doen binnen je Eigen Gemeenschap.' Zemzem. Tijdschrift over het Midden-Oosten, Noord-Afrika \& Islam (1): 124-131.

. 2018b. 'Speaking of the Dead: Changing Funeral Practices among Moroccan Migrants in the Netherlands and Belgium.' In Women and Social Change North Africa: What Counts as Revolutionary?, edited by Doris Gray and Nadia Sonneveld, 215-236. Cambridge: Cambridge University Press.

Low, Setha. 2017. Spatializing Culture. The Ethnography of Space and Place. London \& New York: Routledge.

Mahmood, Saba. 2009. 'Reason and Secular Affect: An Incommensurable Divide?' Critical Inquiry 35 (4): 836-862.

2005. Politics of Piety: The Islamic Revival and the Feminist Subject. Princeton, NJ/Oxford: Princeton University Press.

Massey, Doreen. 1994. Space, Place, and Gender. Minneapolis: University of Minnesota Press.

McLoughlin, Seán. 2013. 'Organizing the Hajj-going from Contemporary Britain: A Changing Industry, Pilgrim Markets and the Politics of Recognition.' In The Hajj: Collected Essay, edited by Venetia Porter and Liana Saif, 241-252. London: The British Museum Press.

McNay, Lois. 2005. 'Agency and Experience: Gender as a Lived Relation.' Sociological Review 52 (2): 173-190.

Sayeed, Asma. 2016. 'Women and the Hajj.' In The Hajj. Pilgrimage in Islam, edited by Eric Tagliacozzo and Shawkat Toorawa, 65-84. Cambridge/New York: Cambridge University Press.

Schielke, Samuli. 2010. Second Thoughts about the Anthropology of Islam, or How to Make Sense of Grand Schemes in Everyday Life. Berlin: ZMO Working Papers.

Schielke, Samuli and Liza Debevec. 2012. 'Introduction.' In Ordinary Lives and Grand Schemes. An Anthropology of Everyday Religion, edited by Samuli Schielke and Liza Debevec, 1-16. New York/Oxford: Berghahn Books. 